\title{
The role of the adrenal glands in tonic immobility (TI) in chickens
}

\author{
JAY BEDINGFIELD, MARGARET HOWARD, and RICHARD W. THOMPSON \\ Western Washington University, Bellingham, Washington 98225
}

\begin{abstract}
Eighteen bilateral adrenalectomized and 19 sham-operated cockerel chicks were tested for duration of tonic immobility (TI) $24 \mathrm{~h}$ after surgery. Although there was no difference in TI duration between groups, adrenal weights of the sham-operated group correlated .733 with TI duration. It was suggested, however, that the correlation may have been an artifact of other factors in the experiment.
\end{abstract}

Tonic immobility (TI), which is characterized by profound behavioral inhibition, tonicity of the muscles, and reduced responsiveness to external stimulation, has been observed in a wide variety of species from arthropods to man. The response, which is typically brought about by brief restraint, has been hypothesized by Ratner (1967) to be the last stage in predator defense. Consistent with this hypothesis are the observations of Sargeant and Eberhardt (1975) that ducks that show TI when captured by foxes are more likely to survive than ducks that do not. In addition, a number of investigators have hypothesized that fear is involved in the response in some way (Gallup, 1974; Ratner, 1967). A number of variables associated with fear have been shown to modify the duration of the response. For example, shock presented prior to TI induction will prolong the response, and tranquilization or habituation to the induction procedure will shorten the duration of TI (Gallup, Creekmore, \& Hill, 1970; Gallup, Nash, \& Brown, 1971; Ratner \& Thompson, 1960).

Further support for the involvement of fear in TI has come from a number of studies that have shown that either epinephrine or norepinephrine injections prior to testing for TI will prolong the response in chickens (Braud \& Ginsburg, 1973; Thompson \& Joseph, 1978; Thompson, Scuderi, \& Boren, 1977; Dunlap, Hennig, Harston, \& MacPhee, Note 1). Amstey and Moore (1962), however, found that epinephrine decreased the duration of TI in young goats. Other reversals of drug effects have been noted between birds and mammals (see Woodruff, Hatton, Frankl, \& Meyer, 1976).

The role the adrenal glands might play in the mediation of TI is not clear. It would be expected that the sympathetic activation that accompanies fear would involve the adrenal gland. Gallup, Ledbetter, and Maser

Jay Bedingfield is now at the University of Oklahoma at Oklahoma City. Requests for reprints should be sent to Richard W. Thompson, Department of Psychology, Western Washington University, Bellingham, Washington 98225. This research was reported at Midwestern Psychological Association meeting, Chicago, May 1979.
(1976) compared the adrenal weights of two strains of chickens that differed markedly in TI durations. Although they found that the strain with the heavier adrenals also showed the longer TI durations, this difference was not significant.

A number of observations on mammals have also suggested a relationship between fear and the adrenal glands. Both adrenalectomy and adrenal demedullation have been shown to impair acquisition (Levine \& Soliday, 1962) and retention (Moyer \& Korn, 1965) of an avoidance response. However, Weiss, McEwen, Silva, and Kalkut (1969) found that adrenalectomized rats showed better retention of an avoidance response than did sham-operated controls. They concluded that adrenalectomy increased fear in rats.

A number of other observations also suggest that the adrenal glands in chickens may be related to TI durations. Crawford (Note 2) found an inverse relationship between peck order and TI durations. Siegel and Siegel (1961) found that during the period of peck-order formation, birds low in the order had larger adrenals than birds high in the order. One could infer that since both adrenal weight and TI durations are negatively correlated with peck order, adrenal weight and TI durations should be positively correlated. Siegel and Siegel (1961) also observed that birds housed singly had smaller adrenals than did group-housed birds. Research in our laboratory (Murphy \& Thompson, Note 3 ) and in a number of others (Gagliardi, 1977; Salzen, 1963) has indicated that isolated birds show much shorter durations of TI than do group-housed birds.

The purpose of the present experiment was twofold: First, does the removal of the adrenal glands have any effect on the susceptibility to or the duration of TI in chickens? Second, is there a correlation between adrenal weight and the susceptibility to TI or its duration?

\section{METHOD}

The experiment was conducted in two replications, 18 birds in the first and 20 in the second. Supplier, housing conditions, apparatus, and procedures were the same in both parts of the study. 


\section{Subjects}

Thirty-eight White Leghorn cockerel chicks were obtained during the 1st posthatch day from a local hatchery. The birds were group housed in a commercial brooder, with food and water available ad lib. The lights were on in the colony room from 7:00 a.m. to 7:00 p.m. The birds were tested 21-31 days posthatch.

\section{Apparatus and Procedure}

Forty hours prior to testing, pairs of birds were haphazardly selected from the brooder, placed together in a holding brooder, and deprived of food for $16 \mathrm{~h}$ prior to surgery. (Pilot work in our laboratory has indicated that fasting the birds before the surgery increases their probability of survival.) Twenty-four hours prior to testing, one of each pair of birds was randomly assigned to the sham-operated group and the other to the adrenalectomy group. For both the adrenalectomy and the sham operation, the birds were anesthetized by ether and bilateral incisions were made between the second and third ribs (counting from the bottom). The ribs were retracted and the underlying muscle and tissue were cut, exposing the adrenal glands. In sham animals the adrenal glands were lightly touched, and the incisions were closed with sutures. For the adrenalectomized birds, the glands were gently separated from the surrounding tissue, the capsule containing the gland was split open, and the adrenal tissue was aspirated out of the capsule using a medicine dropper tipped instrument. The incisions were then closed with sutures. Following the surgery, which lasted 20-30 min, the birds were returned to the holding brooder, where food and water were available ad lib.

The birds were tested for TI $24 \mathrm{~h}$ following surgery. For testing, the birds, one at a time, were removed from the brooder, placed in a carrying box, and taken to the test room. The bird was removed from the box and placed in a test chamber that measured $30 \mathrm{~cm}$ square by $46 \mathrm{~cm}$ high. Three walls of the box were of unpainted plywood, and the floor was covered with 1 -cm-thick plastic-coated foam rubber. The front of the box was of black burlap, split down the middle to provide ready access to the bird. The cloth reduced visual contact of the bird with the experimenter. Immediately after the bird was placed in the test chamber, the experimenter reached through the opening in the cloth and gently grasped the bird and turned it on its side. The bird was held down for $15 \mathrm{sec}$ and then was slowly released. TI was timed from release until spontaneous righting occurred or $3,000 \mathrm{sec}$ had elapsed. If a bird failed to stay down at least $5 \mathrm{sec}$, it was immediately reinduced, inductions continuing until the bird did stay down or five inductions had been given.

One hour after the test for TI, the birds were killed with ether. Adrenalectomized birds were examined to determine if all adrenal tissue had been removed. One bird was found to still have some adrenal tissue and was discarded from the experiment. Sham-operated birds had the adrenals removed, and the tissue was stored at below $0^{\circ} \mathrm{C}$ for 1 week and then weighed.

\section{RESULTS AND DISCUSSION}

Although the adrenalectomized group had a lower mean duration of $\operatorname{TI}(951.38 \mathrm{sec})$ than the sham-operated group $(1,153.22 \mathrm{sec})$, this difference was not significant $(\mathrm{F}<1)$. Only one animal required more than one induction trial, and only three animals reached the maximum of $3,000 \mathrm{sec}$, two in the sham group and one in the adrenalectomized group. It would appear that removing the adrenal gland had no effect on susceptibility to or the duration of TI in chickens, at least when tested $24 \mathrm{~h}$ after the surgery.

Pearson product-moment correlations between TI and adrenal weight and body weight for each replication and for the replications combined are presented in Table 1 . As can be seen from this table, TI duration is significantly correlated with adrenal weight. (Correlation of TI with the ratio of adrenal weight to body weight for each subject for both replications separately and combined revealed rs $<.16$; none of these correlations was significant.) Given that there was no apparent effect of adrenalectomy on TI duration, it would seem likely that the correlations in adrenal weight with TI durations seen in this experiment were a result of some other factor or set of factors.

One such factor could be order of testing. The time required to perform surgery, testing, and postmortems made it difficult to test more than one pair of birds each day. Thus some birds were tested at 21 days of age, and others, not until they were 10 days older. Additional correlations were computed for each replication for the order in which the animal was tested and TI, total adrenal weight, and body weight. These correlations are presented in Table 2 . The order in which the animals were tested correlated significantly with TI duration only in the second replication. The older the bird (the later it was tested), the longer the TI durations. Prestrude (1977) and Ratner and Thompson (1960) found that TI shows little change as a function of age after the first 5-7 days. However, a number of other factors may have produced the changes in adrenal weights and the correlated changes in TI duration. For example, selection of the birds for surgery each day usually resulted in some chasing of the birds and a number of attempts and failures to capture a bird before it was caught. Birds selected later in the experiment would have had much more opportunity to be bumped and chased than those selected early. Although incidental handling might be

Table 1

Pearson Product-Moment Correlations of TI Durations with Adrenal Weights and Body Weights for Both Replications and the Replications Combined

\begin{tabular}{lrlc}
\hline Replication & $\mathrm{N}$ & $\begin{array}{c}\text { Adrenal } \\
\text { Weight }\end{array}$ & $\begin{array}{c}\text { Body } \\
\text { Weight }\end{array}$ \\
\hline First & 9 & $.662^{*}$ & .507 \\
Second & 10 & $.682^{* *}$ & .227 \\
Combined & 19 & $.733 \dagger$ & .447 \\
\hline
\end{tabular}

${ }^{*} p<.10 . \quad{ }^{* *} p<.05 . \quad t p<.01$.

Table 2

Pearson Product-Moment Correlations of Run Order with TI Duration, Adrenal Weight, and Body Weight for Each Replication

\begin{tabular}{lrccc}
\hline Replication & $\mathrm{N}$ & $\begin{array}{c}\text { TI } \\
\text { Duration }\end{array}$ & $\begin{array}{c}\text { Adrenal } \\
\text { Weight }\end{array}$ & $\begin{array}{c}\text { Body } \\
\text { Weight }\end{array}$ \\
\hline First & 9 & .491 & .421 & $.980^{*}$ \\
Second & 10 & .539 & $.817^{*}$ & $.877^{*}$ \\
\hline
\end{tabular}

${ }^{*} p<.01$. 
expected to reduce TI durations (Ratner \& Thompson, 1960), Nash and Gallup (1976) have shown that it is the TI-induction procedure that is most important in reduction of TI durations from habituation. In addition, Tortora and Borchelt (1972) have found that escape responses elicited prior to testing for TI will prolong the response. One might expect the stress of the chase to both produce larger adrenals and prolong TI durations.

Another factor that might have increased stress, and thus caused larger adrenals and longer TI, was the continued disruption of the peck order in the home brooder by the removal of a pair of birds each day. Siegel and Siegel (1961) found that disrupting the peck order promoted adrenal growth.

As a further test of the relationship between adrenal weights and TI durations, 10 birds from another experiment, obtained from the same supplier and maintained as the birds in the first experiment except for the daily disruptions, food deprivation, and surgery, were tested for TI duration following an injection of saline. There was no restriction placed on the duration of TI for these animals, and all birds were tested on the same day. Following TI testing, the birds were sacrificed, and their adrenals were removed and stored for 1 week at below $0^{\circ} \mathrm{C}$.

The correlation of TI with adrenal weight was $r=.426$, but it was not significant. The correlation of TI with body weight was $\mathrm{r}=.316$; this was also not significant.

It would seem most parsimonious at this point to conclude that the correlation of TI with adrenal weight observed in the sham-operated control subjects was a result of the daily stress to which these animals had been subjected. The stress both caused the adrenal weights to increase and prolonged TI durations.

\section{REFERENCE NOTES}

1. Dunlap, W. P., Hennig, C. W., Harston, C. T., \& MacPhee, A. A. Tonic immobility and the adrenergic system: Differential effects of alpha, and alpha $a_{2}$ agonists. Paper presented at the meeting of the Psychonomic Society, San Antonio, November 1978.

2. Crawford, F. T. Pecking order and animal hypnosis in the chicken. Paper presented at the meeting of the Southeastern Psychological Association, Atlanta, April 1972.

3. Murphy, J., \& Thompson, R. W. Effects of social or isolated rearing on tonic immobility in chickens. Unpublished manuscript, 1978.

\section{REFERENCES}

Amstey, M., \& Moore, A. U. Tonic immobility: Decreased inhibitory activity as an effect of three different drugs in the induced catatonic state in goats. American Zoologist, 1962, 2, 502 .

Braud, W. G., \& Ginsburg, H. J. Effect of administration of adrenalin on immobility reaction in domestic fowl. Journal of
Comparative and Physiological Pssychology, 1973, 83, 124-127. GAGLIARDI, G. J. Effects of social isolation on tonic immobility in chickens (Doctoral dissertation, State University of New York at Albany, 1977). Dissertation Abstracts International, 1977, 38, 2420B.

Gallup, G. G., Jr. Animal hypnosis: Factual status of a fictional concept. Psychological Bulletin, 1974, 81, 836-853.

Gallup, G. G., Jr., Creekmore, H. S., \& Hill, W. E., III. Shock enhanced immobility reactions in chickens: Support for the fear hypothesis. Psychological Record, 1970, 20, 243-245.

Gallup, G. G., JR., Ledbetter, D. H., \& Maser, J. D. Strain differences among chickens in tonic immobility: Evidence for an emotionality component. Journal of Comparative and Physiological Psychology, 1976, 90, 1075-1081.

Gallup, G. G., Jr., Nash, R. F., \& Brown, C. W. The effects of a tranquilizer on the tonic immobility reaction in chickens: Additional support for the fear hypothesis. Psychonomic Science, $1971,23,127-128$.

Levine, S., \& Soliday, S. An effect of adrenal demedullation on the acquisition of a conditioned avoidance response. Journal of Comparative and Physiological Psychology, 1962, 55, 214-216.

MOYER, K. E., \& KorN, J. H. Effect of adrenalectomy and adrenal demedullation on the retention of an avoidance response in the rat. Psychonomic Science, 1965, 2, 77-78.

Nash, R. F., \& Gallup, G. G., JR. Habituation and tonic immobility in domestic chickens. Journal of Comparative and Physiological Psychology, 1976, 90, 870-876.

Prestrude, A. M. Some phylogenetic comparisons of tonic immobility with special reference to habituation and fear. Psychological Record, 1977, 1, 21-39.

RATNER, S. C. Comparative aspects of hypnosis. In J. E. Gordon (Ed.), Handbook of clinical and experimental hypnosis. New York: Macmillan, 1967.

RAtNer, S. C., \& Thompson, R. W. Immobility reactions (fear) of domestic fowl as a function of age and prior experience. Animal Behaviour, 1960, 8, 186-191.

SAlzen, E. A. Imprinting and the immobility reactions of domestic fowl. Animal Behaviour, 1963, 11, 66-71.

Sargeant, A. B., \& Eberhardt, L. E. Death feigning by ducks in response to predation by red foxes (Vulpes fulva). American Midland Naturalist, 1975, 94, 108-119.

Siegel, H. S., \& Siegel, P. B. The relationship of social competition with endocrine weights and activity in male chickens. Animal Behaviour, 1961, 9, 151-158.

Thompson, R. W., \& JoSEPH, S. The effect of norepinephrine on tonic immobility in chickens. Bulletin of the Psychonomic Society, 1978, 12, 123-124.

Thompson, R. W., Scuderi, R., \& Boren, J. The effect of epinephrine on tonic immobility (animal hypnosis) in chickens. Bulletin of the Psychonomic Society, 1977, 9, 409-410.

Tortora, D. F., \& Borchelt, P. L. The effect of escape responses on immobility in bobwhite quail (Colinus virginianus). Psychonomic Science, 1972, 27, 129-130.

Weiss, J. M., McEwan, B. S., Silva, M. T., \& Kalkut, M. F. Pituitary-adrenal influences on fear responding. Science, 1969, 163, 197-199.

Woodruff, M. L., Hatton, D. C., Frankl, M. B., \& Meyer, M. E. Effects of scopolamine and physostigmine on tonic immobility in ducks and guinea pigs. Physiological Psychology, 1976, 4, 198-200.

(Received for publication May 13, 1980.) 